\title{
DO REGIONAL AIRLINES IN EASTERN EUROPE HAVE THE RIGHT TO SURVIVE IN THE EUROPEAN SINGLE SKY ENVIRONMENT?
}

\author{
Sven KUKEMELK ${ }^{1,2}$ \\ ${ }^{1}$ Nordic Aviation Group, Sepise 1, Tallinn, 11415, Estonia \\ ${ }^{2}$ Tallinn University of Technology, Department of Economics and Business Administration, \\ Akadeemia tee 3, Tallinn, 12618, Estonia \\ E-mail:sven@eava.ee
}

Received 15 June 2017; accepted 06 December 2017

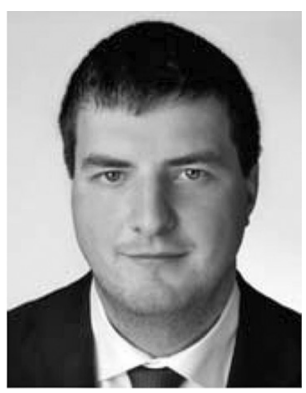

Sven KUKEMELK

Education: Estonian Aviation Academy (2010), Vilnius Gediminas Technical University (2012), Tallinn University of Technology, PhD studies (since 2013).

Experience: 7 years of experience in network planning and aviation business analysis. Research interests: network planning, fleet development, commercial management. Present position: CEO of Nordic Aviation Advisory, Executive Director for Business Development at Nordic Aviation Group.

Abstract. The European aviation market can be characterised by extreme growth and turbulence ever since the markets were deregulated and low cost carriers emerged on the continent. Initially the biggest toll was paid by main legacy carriers when low costs emerged on trunk routes, which lead to the bankruptcy of Sabena, Swiss airlines and Spanair. However, once big legacy carriers started merging and creating more alliances, sustainability was once again reached. Despite this, as low cost carriers entered the Eastern-European market and looked to stimulate even smaller regional routes, smaller carriers started to suffer. This article is assessing the status quo of the current European regional aviation, highlighting the recent trends and ultimately coming to a conclusion that regional airlines can be sustainable provided that certain key criteria have been met. ulations.

Keywords: aviation management, commercial development, airlines, bankruptcy, regional aviation, state aid reg-

\section{Introduction}

Europe (especially the European Union) is one of the biggest aviation markets in the world, second only to North-America (IATA 2015), and has seen rapid growth in passenger numbers over the last 10 years. According to the Airbus (2016) study, the traffic from/to /within Europe has grown by $59 \%$ from 2005 to 2015 . It is also well projected into the future that such a growth rate will continue for the next 20 years and, based on the Airbus global forecast (ibid.), that air traffic doubles in every 15 years; however, most likely at a slower pace in mature markets such as Europe. This article analyzes what these changes so far have brought and what could still be in the pipeline for the future across the aviation sector in Europe. The main research object here is the regional airline model and its chance for survival. This is the first study looking at the regional airline business model difficulties, especially from the Eastern-European perspective within the Single Sky framework. As aviation data is hard to collect, the source material has come from reputable data providers such as Airport-IS, IATA, Innovata and OAG.

The first part of the paper describes the historical background with reasoning on how we have come to a situation with such examples. The second part is about the external constraints of regional aviation and concentrates on the European legislative struggles in the aviation field. The third part focuses on an outlook to the future of regional aviation, which is also supported with the views from other academic scientists in the 
field presenting the current research done and their view to different scenarios that could happen in the years to come. The fourth part describes the current fragile economic balance of regional aviation and explains the research object. This is followed by a description of the core essence of the research problem which has created the instability in the regional aviation market and how it could be overcome in the fifth part. Finally, there is a conclusion which sums up the research and confirms the conditions which need to be met to make regional aviation sustainable.

\section{Historical background of the situation}

In the last 3 decades, a major issue for airports has been to cope with the capacity growth as they have been faced with an extreme growth in passengers numbers at immense speed. Of course, this growth has been supported by the increased competition which effectively reduced the ticket prices and drove the demand for bigger aircraft, which reduced the cost per seat. Additionally, this has been supported by the growing economy in Europe as well as globalization and decentralization of national boundaries.

The main developments which clearly indicate the growing passenger volumes in Europe to be highlighted are listed below.

1) Openings of new runways:

- Frankfurt's new runway Northwest, since 2011 (Fraport 2015);

- Helsinki's new third runway, 2002 (CAA Finland 2003);

- Barcelona El Prat's third runway, 2004 (Aena Barcelona 2017);

- Manchester Airport's second runway, 2001 (Manchester Airport 2017).

2) Openings of new terminals:

- Heathrow's Terminals 2 and 5, opened respectively in 2012 and 2008 (LHR Airport limited 2017);

- Madrid Barajas' Terminal 4, opened in 2006 (Aena Madrid 2017);

- Munich's new pier at Terminal 2, opened in 2016 (FMG 2016);

- Vienna’s Terminal 3, 2012 (Fulghafen Wien 2013).

3) Construction of completely new airports:

- Athens' new airport, opened in 2001 (Dixon 2010);

- Oslo's Gardermoen airport, opened in 1998 (Bredal 1998);

- Berlin's Brandenburg, to be opened in 2019 at the latest (Hall 2016);

- Istanbul's new airport, to be opened in 2018 (Daily Sabah 2016);
- Warsaw's new airport, to be opened in 2027 (Radio Poland 2017).

At the same time, the structure of the airlines carrying these passengers has changed quite significantly. With the liberalization of the European airspace and extension of the open skies through the enlargement of the European Union (especially the big enlargement in 2004), low cost carriers moved from a niche player status to a trend setter position. As historic bilateral barriers were torn down, low cost carriers were able to fly freely between any city-pair inside the single sky. That effectively meant that, for example, passengers originating from London going to Sweden could be carried by a Romanian airline using Irish cabin crew based in Estonia.

The initial interest of the low cost carriers was only to serve the biggest city pairs, as they had a significantly lower cost-base than the legacy carriers and could exploit that by taking the more price sensitive passenger segment for themselves. This lead to the first wave of bankruptcies and restructurings in Europe with the ceasing of operations by:

- Sabena, the flag carrier of Belgium;

- Swiss, the flag carrier of Switzerland;

- Olympic Airways, the flag carrier of Greece;

- Alitalia, the flag carrier of Italy.

The majority of the national carriers (Alitalia, airBaltic, Malev, LOT, TAP, Cyprus Airways, Estonian Air, SAS) in the course of the low cost revolution went through a painful restructuring process which in many cases included the support of public money to keep the airlines flying. The individual states felt that low cost carriers do not solve their connectivity issues because:

- low cost carriers usually tend to fly at low frequencies (due to big aircraft which drive the seat cost down), which is not suitable for business people;

- low cost carriers fly a lot of seasonal routes which do not take into account business people's needs (Ryanair grounds $1 / 3$ of their fleet for the winter season);

- low cost carriers fly at times that provide the highest efficiency rather than the highest connectivity or premium times (departing at 6 am instead of 8 am for example);

- low cost carriers do not provide the connectivity which is needed for business people (beyond hub airports).

Because of these reasons, individual states and municipalities felt that there is no real alternative to having a national carrier and, therefore, decided to make capital investments to airlines as this kept regional municipalities content and provided control over the connectivity during the financial crisis. This, however, lead to new legislation by the European Union to avoid distortion of 
the competition, as state money was seen as a distortion of the competitive landscape of the market.

\section{Legislative barriers which guide the European regional landscape}

In general, aviation related topics are not covered too well in scientific journals; however, there are still some publications to be found. The market deregulation, and the ways of creating low cost carriers have been covered best by Button (2000), Oum (2000), Pels (2000), Barret (2004) and Ceto (2009). Their work was fundamental in establishing the reasoning behind the deregulation of the aviation markets in Europe, the Asia-Pacific region and the USA; however, it only concentrated on the supply-demand and the concentration of the market in the eyes of globalization. Furthermore, there is no literature which would look into the effects of the state-aid-legislation and its impact on the European aviation market, especially from the view point of regional airlines, which in the author's view have suffered the most. Therefore, a short analysis on the impact of legislative barriers or, in this case, the state-aid regulation on the European aviation sector is presented.

Since a number of airlines are listed in the public stock exchange markets (SAS, Lufthansa, Air France, British Airways, etc.), lobby groups emerged supporting the European Union in implementing legislation against the usage of public money to support struggling national carriers (Ceto 2009). As a result, the European Union decided to pass a state aid legislation which also covers regional airlines and new member state airlines in Eastern-Europe.

Ever since the state aid legislation was adopted in 2005, the European Union has almost religiously avoided any interference in the European aviation market by public money (Official Journal of the... 2014a). Such a development has led to a situation where regional airlines were hit the hardest. The already bankrupt airlines of Malev, Spanair, Fly Lal, Transaero, and OLT were joined by Cyprus Airways, Air Lituanica and Estonian Air. A recent decision by the European competition authority to clear the state aid investigation accusations for SAS, LOT Polish, Adria Airways, Czech Airlines, and Air Baltic, demonstrates that regional airlines seem to be especially high-risk victims together with the airlines situated further away from the heart of Europe. However, to get back to the starting point one needs to understand what EU state aid regulation really is and why it was implemented. The EU state aid regulation governs that the public sector is not allowed to make any capital injections to airlines with the following exceptions (Official Journal of the... 2014b):

1) a state is allowed to make one time capital investments into airlines once every 10 years to support change in strategical decision based on ex ante principal (provided that there is a justified expectation for profit) (point 8.3 section 164);

2) a state is allowed to make capital investments into the airline if it can prove that the private sector would do likewise (point 3.5.2 section 61).

These plans are then assessed by the European Union competition authority to assess the level of distortion made by a carrier receiving state aid and measures that such an airline would take to ensure a reduction of (or limited) distortion. These measures are almost always reductions in the fleet, network. and the number of seats offered. which in general supports the idea of consolidation of the aviation market in Europe.

Based on the regulation, regional airlines need to make their strategy plans for 10 years without getting additional capital for a changing environment. In a world of changing times this is quite difficult to execute, as aviation continues to see an increase in tremendous losses due to one time external factors such as the Icelandic volcanic eruption, Ebola virus, Russian-Ukrainian crisis, an economic collapse of tremendous proportions (2009 recession), Arab Spring, different terror attacks (Brussel airport terror attack, Paris terror attack, Nice terror attack, etc.), etc.

While governments are allowed to support bus companies during economic downturns, ferry operators, train conglomerates however aviation have been chosen as the place for fair play. One of the main causes for that comes from the early 2000s, when low cost carriers started to emerge in Europe by engaging regional airports which fell into disuse with the development of enhanced ground transportation (bullet trains and new highways) and were looking for ways to survive.

Such small secondary airports reduced their charges to non-sustainable levels to become attractive to the new breed of airlines - low cost carriers (Botond 2004). As traditional carrier network planning is done in search of solid business demand between major cities out of which one is the hub airport (the base of the airline), the regional airports were looking for alternative solutions. With the help of numerous consultants and advisors who continued to emphasize the benefits of aviation to local governments and municipalities, public funding (mostly municipal) was allocated to support operating the airports below market prices with additional financial support granted to low cost carriers (Kukemelk 2014).

\section{Regional airline business model difficulties}

Actually, such a move meant that small secondary airports were partly able to reverse the traffic development trends and make more effective use of the developing infrastructure and lure more people from secondary 
airports with low (effectively subsidized) prices. As low cost carriers continued to enjoy financial support which provided a cost-base well below the ones of legacy carriers, traditional airlines started to lobby for more transparent policies for aviation. That meant that public money should be limited when supporting airports and airlines to ensure a transparent and competitive landscape for all industry participants.

Unfortunately, this step hit the regional airlines hardest, and not low cost carriers. As low cost carriers continued to make marketing agreements which as such could not be forbidden with existing legislation, regional carriers, which were mostly state owned, had to compete with their high cost-base and in many cases had to execute the state's aviation strategy, which left limited chances for sustainable business development (airBaltic, Tarom, LOT, etc.). As states did not accept downsizing of the airlines' networks or fleets in fear of job loss and economic downturn just before the next elections, the airlines had to start taking increasingly drastic steps for survival. Change of management became ever more common, for example, in a 3-year time period (from 2006-2009), LOT Polish had 7 CEOs each implementing their own strategy (LOT Polish 2016).

Whilst these problems created significant financial trouble for airlines under full or partial state control, independent carriers resumed to function in sound economic conditions. Some of these airlines are, for example, BMIregional, Wideroe, Luxair, Darwin, Malmö Aviation, and others. However, what is also common for most of them is that apart from being private (or mostly private) they are also situated in very developed countries such as UK, Norway, Luxembourg, Switzerland, and Sweden. It can be argued that their results were not hindered as much as those of other airlines in Europe during the last recession due to the fact that their respective home countries had only a limited exposure to the crisis.

At the same time private regional carriers in Eastern-Europe suffered greatly with Carpatair being in insolvency and closing its scheduled services, and OLT Poland together with Aerosvit suffering full bankruptcy (CH-aviation 2014). This shows that the impact on the aviation market in Europe was not on equal terms in Western-Europe as in Eastern-Europe, also the reserves to cope with such a crisis were significantly different on both sides of Europe.

\section{Implications arising from the situation}

As regional carriers started to shrink in size eventually, troubled regional airports (many capital airports such as Riga, Vilnius, Tallinn, Warsaw, Prague, Bucharest, Budapest, Sofia, etc.) started looking for ways to increase passenger output. The main growth engines out there were low cost carriers, which were willing to start flights from these (secondary) airports for low charges and substantial marketing support. This reduced the regional airlines competitiveness even further, as they were unable to compete for the price-sensitive market segment.

Due to financial difficulties, governments made capital investments to keep the airlines afloat hoping for a positive reaction from the European Union. Unfortunately in the case of Malev, Cyprus Airways, and Estonian Air, it did not come through and carriers ceased operations after the claim of the European Commission to pay back the illegal state aid. Others, such as Air Baltic, LOT Polish, and SAS, got some extra time as their state aid support plans were accepted by the European Commission and they can now implement them over the next 10 years.

I do not claim that the only reason for the demise of regional airlines is the low-cost subsidies from the regional airports as there is and was a lot of inefficiency as well. Being a small airline with a long history, union agreements, certain setup, and a hierarchic workforce with a historically potentially expensive or inefficient fleet, reduced the airlines' survival options. However, these issues could have been solved with proper restructuring and capital investment, provided that there is will.

All of these reasons are very valid and clear, and there are no plans to alter the path of low cost emergence in Europe. On the contrary, competition has become a bit more fair in recent years, as the European Commission finally identified the root cause of uncompetitive regional airlines. In the beginning of 2014, a new regulation was introduced on state aid legislation and also on airports (European Commission 2014, new State). Nevertheless, the question is do regional airlines have a future to count on. We can conclude that low cost aviation has come to stay and even to grow further. At the same time in the European Union, big established traditional carriers such as Lufthansa, IAG, and Air France-KLM, will most likely survive. However, their survival comes at the cost of adapting to the market. In their group, all three carriers have at least one low-cost carrier (Lufthansa with Eurowings, IAG - Vueling, and Air-France-KLM Transavia), and they have had to make significant cuts in their services offered to customers limiting items which were historically considered to be the identifiers of a traditional carrier, such as:

- free baggage (Lufthansa, KLM, and Air France, charge for checked luggage);

- free meals on board (KLM and Air France dropped free cabin service);

- bigger seat pitch on board the plane (Lufthansa and British Airways have a seat pitch from 30 inch and up, Air France 31 inch and up, whereas Norwegian, which is a low cost, has it between 29-31 inches). 
The majority of the struggling regional carriers in Europe have their operational bases in Eastern-Europe. Eastern-Europe, having lower productivity and lower cost of living, is still trying to cope with the introduction of market economy. Based on the main macroeconomic indicators, such as average salary, GDP per capita, and foreign direct investment portion, one can draw couple of conclusions:

- salaries are lower than in Western-Europe (due to multiple structural and institutional circumstances), leading to a lower cost base;

- due to lower salaries, consumer purchasing power is lower, resulting in reduced purchasing power and hence lower potential for air travel;

- as airline business is volume business (especially aircraft acquisition), those regional carriers also face higher capital-cost.

\section{Traffic origin}

Since the majority of the traffic in Eastern-European countries is on the east-west axis, it means that Eastern-European airlines mostly fly towards Western-Europe whereas carrying mostly people originating from Western-Europe (due to higher purchasing power). When researching the amount of routes available for selection from Eastern European capital cities, it is obvious that the highest amount of routes is concentrated towards Western Europe in comparison with Eastern Europe.

For research purposes, the airports chosen represent the bigger and most representative sample of main airports of Eastern-European capitals as seen on Figure 1:

- Warsaw Chopin Airport;

- Budapest Airport;

- Prague Airport;

- Riga Airport;

- Vilnius Airport;

- Bucharest Airport.

The route is considered to be going to Western-Europe if it is bound for the following countries: Germany, Netherlands, Belgium, Luxembourg, United Kingdom, Ireland, Iceland, Norway, Sweden, Finland, Denmark, Austria, Switzerland, France, Spain, Portugal, Italy, Greece, Cyprus, and Malta.

The route is considered to be going to Eastern-Europe if it is bound for following countries: Estonia, Latvia, Lithuania, Poland, Czech Republic, Slovakia, Hungary, Slovenia, Croatia, Serbia, Bosnia- Herzegovina, Montenegro, Kosovo, Albania, FYR Macedonia, Bulgaria, Romania, Moldova, Ukraine, Russia, Georgia, Armenia, and Azerbaijan.

The differentiation can be seen on the map (Fig. 2), where Eastern-Europe is in orange and Western-Europe is in blue in compliance with the list presented above.
This study does not look into domestic routes and long-haul routes to the rest of the world to keep the data comparable. In Eastern-Europe, domestic routes are really only a significant portion of the routes in Poland, Ukraine, and Romania. However, taking them into account would not highlight the real traffic direction and flows. The same applies for long-haul flights which would be difficult to position in any of these fields and which only represent a small portion of the traffic originating from Eastern Europe.

Based on the analysis summarized in Table 1, it is clear that the majority of the routes and, consequently, the majority of the traffic is travelling on the east-west axis inside Eastern-Europe. On the basis of data of the selected Eastern-European airports, on average $78 \%$ of all routes head towards the West (based on the criteria set above) and only $21 \%$ go to the east. Bucharest has the highest share of West-bound flights (91\%), while Kiev's Boryspil has the lowest one with only more than half of the flights heading West (56\%).

These results exclude intercontinental flights and domestic flights. The results of the analysis can be seen in Table 2 highlighting the percentage of all flights taking place to a certain direction. The data has been collected

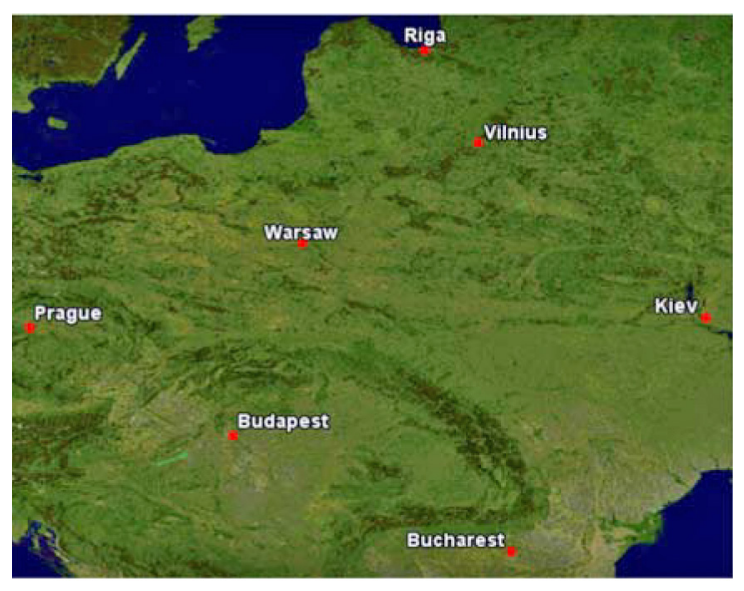

Fig. 1. Airports included in the route study on the Great-circle mapper

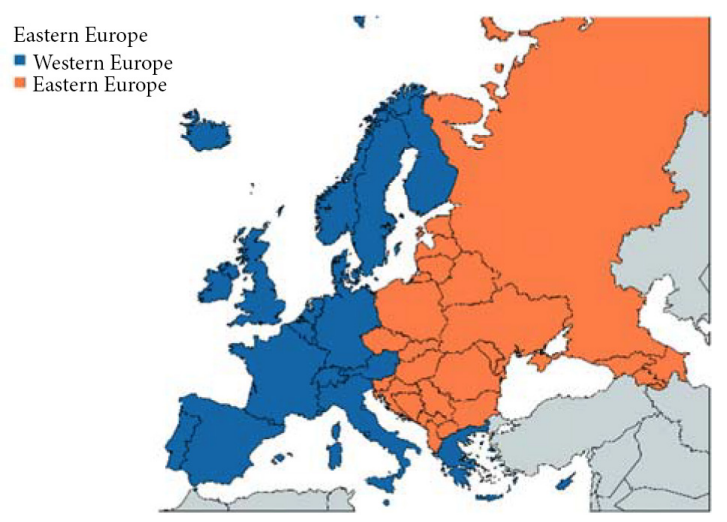

Fig. 2. List of countries distributed into the Eastern- and Western-Europe directions 
Table 1. List of routes to Eastern-Europe and Western-Europe

\begin{tabular}{lll}
\hline Airport & $\begin{array}{l}\text { Routes Western- } \\
\text { Europe }\end{array}$ & $\begin{array}{l}\text { Routes Eastern- } \\
\text { Europe }\end{array}$ \\
\hline $\begin{array}{l}\text { Warsaw Chopin } \\
\text { Airport }\end{array}$ & 92 & 39 \\
\hline $\begin{array}{l}\text { Budapest Ferenc } \\
\text { Liszt Airport }\end{array}$ & 107 & 18 \\
\hline Vilnius Airport & 59 & 13 \\
\hline Riga Airport & 69 & 22 \\
\hline $\begin{array}{l}\text { Prague Vaclav } \\
\text { Havel Airport }\end{array}$ & 143 & 42 \\
\hline $\begin{array}{l}\text { Kiev Boryspil } \\
\text { Airport }\end{array}$ & 40 & 31 \\
\hline $\begin{array}{l}\text { Bucharest Henri } \\
\text { Coanda Airport }\end{array}$ & 123 & 12 \\
\hline
\end{tabular}

from the OAG database (17.10.2016 status). OAG is a global collector and distributor of commercial airline schedules. It is an actual database used by airlines and global distribution platforms for selling tickets and for schedule composition.

The data in Table 2 is based on the total number of routes which qualify for "East" or "West" according to the classification highlighted previously. The total average is calculated by taking the sum of all routes to the West and the sum of all routes to the East.

Table 2. Share of routes to the East and West

\begin{tabular}{lll}
\hline Airport & West bound & East bound \\
\hline Warsaw - WAW & $70 \%$ & $30 \%$ \\
\hline Budapest - BUD & $86 \%$ & $14 \%$ \\
\hline Vilnius - VNO & $82 \%$ & $18 \%$ \\
\hline Riga - RIX & $76 \%$ & $24 \%$ \\
\hline Prague - PRG & $77 \%$ & $23 \%$ \\
\hline Kiev - KBP & $56 \%$ & $44 \%$ \\
\hline Bucharest - OTP & $91 \%$ & $9 \%$ \\
\hline Average & $78 \%$ & $22 \%$ \\
\hline
\end{tabular}

The results highlight that Western-European routes dominate the landscape in the sample airports of Eastern-Europe. There could be several underlying factors at play; however, it is the author's belief that the most fundamental underlying reasons may be that:

- Eastern European companies do not have enough capital yet to make major expansions to other Eastern-European markets, and hence the majority of corporate travel still takes place from West to East;

- Western-European companies are capital rich and are still the basis for most of the business traffic between the East and West;
- Eastern Europe is not interesting enough from the tourism point of view for Eastern European tourists, who, if they travel there, prefer cheaper means of transportation such as trains and buses.

This process will most likely change as Eastern-European living standards are rising; however, as long as the average salary of Eastern Europe remains more than 2 times below the average salary of Western-Europe, it is clear that such developments will take a significant amount of time. Until the gap in the market capitalization and average salaries remain high, it is very likely that high levels of low cost passengers will travel on Eastern-European bound routes (Vidovic et al. 2006).

\section{Conclusions}

Whilst Eastern-European airlines (most of them regional airlines) have a lower personnel cost, they are still faced with a higher capital cost. Additionally, as they are competing for passengers originating mostly not from their home or base country (business traffic originating from Western-Europe), then they need to be:

- cheaper than Western-European airlines (lower cost base due to lower revenue generation ability);

- offering better service than Western-European airlines;

- making bigger investments in marketing to change passengers' travel behavior.

As passenger preference is mostly higher for home carriers (national carriers), the ability to compete for higher paying customers is a significant challenge.

IATA airline financial results combination for European airlines for 2017 is a $2.9 \%$ profit (IATA 2016), which provides some hope for the airline sector as profit margins are back from the lows of 2012 at a mere $0.7 \%$ (IATA 2015). However, the sector average weighted average cost of capital (WACC) is at 6.9\% (IATA 2016), which is high above the profit margins. Furthermore, it is expected that regional carriers in Eastern-Europe have a WACC ranging between $7-10 \%$ at times (based on the author's sole belief founded on his experience of working and consulting Eastern-European airlines), when the interest rates by the ECB are at a record low of $-0.4 \%$ (European Central Bank 2016).

Therefore, it is clear that if regional airlines in Eastern-Europe want to survive, they need to find capital which does not expect any returns. That kind of capital, however, only comes from the governmental sector, which is greatly interested in having its own airlines to secure the jobs and to be responsible for tourism development accessibility in the region.

To come back to the fact that the EC only allows state investments into regional airlines every 10 years, 
only one conclusion can be drawn - if states want to keep their national airlines, they need to make huge one-time investments into their national carriers every 10 years. That, however, guarantees neither sustainability nor fair competition in the European air market, which is the goal of the EC. Bearing that in mind, as we are going to see this kind of investments being made into regional airlines in Eastern-Europe every 10-12 years, we can expect further rule changes from the EC.

The only lifeline for Eastern-European carriers is that the average salaries and purchasing power are rising, so if this continues, then in 30 years time they will have caught up with Western-Europe and they will have become competitive. However, as 30 years is a long time, we do not know what will be the main driving forces in European aviation by then. However, provided that there is a solid business plan and sufficient funding in place, regional airlines can have a sustainable future coming from a lower cost-base and the ability to offer to fly for bigger airlines capitalizing on their lower overhead. This process in the USA made regional airlines sustainable in the 1970-1980s; however, it ceased their own commercial risk operations.

\section{References}

Aena Barcelona. 2017. History of Barcelona El-Prat airport [online], [cited 19 March 2017]. Available from Internet: http://www.aena.es/en/barcelona-airport/history.html

Aena Madrid. 2017. History of Madrid Barajas airport [online], [cited 19 March 2017]. Available from Internet: http:// www.aena.es/en/madrid-barajas-airport/history.html

Airbus. 2016. Mapping demand 2016/2035. Global market forecast, Airbus, Toulouse.

Barret, S. D. 2004. How do the demands for airport services differ between full-service carriers and low-cost carriers, Journal of Air Transport Management 10: 33-39. https://doi.org/10.1016/j.jairtraman.2003.10.006

Botond, K. 2004. Setting airport charges and the way of implementation, Periodica Polytechnica, Transportation Engineering 32(1-2): 43-56.

Bredal, D. 1998. Oslo lufthavn Gardermoen: Porten til Norge. Schibsted, 42.

Button, K. 2000. Handbook of transport modelling. Pergamon, Oxford.

CAA Finland. 2003. Annual report of the CAA 2003. Sävypaino, Helsinki, 18.

Ceto, A. 2009. Challenges in the $21^{\text {st }}$ century, in The Airline industry. Springer, 3 .

$\mathrm{CH}$-Aviation. 2014. Carpatair files for insolvency, continues operations [online], [cited 27 May 2017]. Available from Internet: https://www.ch-aviation.com/portal/news/25225-carpatair-files-for-insolvency-continues-operations

Daily Sabah. 2016. Nearly half of the construction completed at Istanbul's new airport, Daily Sabah online version [online], [cited 29 November 2016]. Available from Internet: https://www.dailysabah.com/tourism/2016/11/30/nearlyhalf-of-construction-complete-at-istanbuls-new-airport

Dixon, T. 2010. Eleftherios Venizelos Athens International Airport, AirlineWorld February 2010: 91.

European Central Bank. 2016. Key ECB interest rates, March 30, 2016.

European Commission. 2014. New state aid rules for a competitive aviation industry. Competition policy brief.

FMG. 2016. New satellite terminal redefines standards of quality, comfort and convenience [online], [cited 19 March 2017]. Available from Internet: https://www.munich-airport.com/ historic-milestone-for-munich-airport-342163

Fraport. 2015. 2015 Facts and figures on Frankfurt airport. AG Frankfurt Airport Services Worldwide, Frankfurt am Main. 5 p.

Fulghafen Wien. 2013. Annual Report 2013. Fulghafen Wien Aktiengesellschaft, Vienna. $223 \mathrm{p}$.

Hall, A. 2016. Top officials may face court over Berlin's "phantom" unfinished airport, The Times online issue [online], [cited 12 February 2016]. Available from Internet: https:// www.thetimes.co.uk/article/top-officials-may-face-courtover-berlins-phantom-unfinished-airport-mf5 $\mathrm{cmmcvbb} 2$

IATA. 2015. IATA Economic industry performance - forecast table (IATA Economics) [online], [cited 19 March 2017]. Available from Internet: http://www.iata.org/whatwedo/ Documents/economics/Central-forecast-end-year-2015tables.pdf

IATA. 2016. Another strong year for airline profits 2017, IATA Press release nr 76 [online], [cited 19 March 2017]. Available from Internet: http://www.iata.org/pressroom/pr/Pages/2016-12-08-01.aspx

Kukemelk, S. 2014. Changes in regional airport landscapes will affect all parties involved and steps should be taken to cope with the new, Journal of Airport Management 8(4): 334-342.

LHR Airport limited. 2017. Our history [online], [cited 19 March 2017]. Available from Internet: http://www.heathrow.com/company/company-news-and-information/company-information/our-history

LOT Polish. 2016. Wladze PLL LOT, in Wikipedia [online], [cited 19 March 2017]. Available from Internet: https:// pl.wikipedia.org/wiki/Polskie_Linie_Lotnicze_LOT

Manchester Airport. 2017. Our history 2001 [online], [cited 19 March 2017]. Available from Internet: http:// www.manchesterairport.co.uk/about-us/manchester-airport-and-mag/history/

Official Journal of the European Union. 2014a. Guidelines on State aid to airports and airlines, C_99/03.

Official Journal of the European Union. 2014b. Guidelines on State aid for rescuing and restructuring non-financial undertakings in difficulty, C_249/01.

Oum, T. 2000. Shaping air transport in Asia Pacific. Aldershot, Ashgate.

Pels, E. 2000. Airport economics and policy. Efficiency, competition, and interaction with airlines. Vrije Universiteit Amsterdam.

Radio Poland. 2017. Ministers back new central airport for Poland, Radio Poland, 15 March 2017.

Vidovic, A.; Steiner, S.; Babic, R. S. 2006. Impact of low-cost airlines on the European air transport market. University of Zagreb Publishing. 